\title{
The Utilisation of Integrated Marketing Communication Strategies by Small Retailers in Mankweng, South Africa
}

\author{
Lethabo M. Mapheto \\ Olabanji. A. Oni \\ Tafadzwa Matiza
}

Department of Business Management, University of Limpopo, Turfloop Campus, Private Bag X1106, Sovenga, 0727 South Africa

Email: olabanji.oni@ul.ac.za

\section{Doi:10.5901/mjss.2014.v5n15p111}

\section{Abstract}

The aim of this study was to investigate whether small retailers in the Mankweng township of Limpopo Province, South Africa make use of intergrated marketing communication to communicate with their customers with the objective to investigate whether these small retailers made use elements of intergrated marketing communication within their businesses and whether the utilisation of integrated marketing communication had an effect on business profitability. From a sample of $\mathrm{N}=26 \mathrm{small}$ retailers, a quantitative survey was conducted through researcher-administered questionnaires, with data being analysed by the Statistical Package for Social Sciences 21. Significantly, the study found that most small retailers in Mankweng utilised elements of intergrated marketing communication, while some had no interest. Also the study found that for those small retailers that employed marketing communication, their profitability was positively impacted. As a result of this study we recommend that small retailers in the area adopt suitable marketing communication strategies as a business approach based on market research, effective resource utilisation and measurable strategic objectives.

Keywords: Intergrated marketing communication, small retailers, profitability, Mankweng,

\section{Introduction}

Small businesses are playing critical roles in absorbing labour, penetrating new markets, and promoting entrepreneurial and innovative activities (Chen, 2009). According to Ntema and Marais (2012) small retailers accounted for up to $28.4 \%$ of South Africa's Gross Domestic Product (GDP), with South Africa's informal outlets contributing an estimated $10 \%$ of the potential retail trade (amounting to approximately R32bn). Integrated Marketing Communication (IMC) involves the planning approach that attempts to coordinate, consolidate and bring together marketing-related communication messages and is a catalyst for the interaction between organisations and their stakeholders (who include customers and suppliers), where the organisation seeks to influence the perceptions of its stakeholders towards the organisation and its products and services (Barker \& Angelopulo, 2006; Du Plessis, Van Heerden \& Cook, 2010). With the increase in competition in the retail sector, it has become necessary for even smaller retailers to try to influence new potential customers and also create brand loyalty (Rodrigo, 2012).

There is limited empirical research on the role of IMC in the small retail sector and the key challenge for retailers has become how to build strong brands by coordinating in-store communications (shopper assistants) with the usual outof-store branding communications (e.g., print advertisement). The under-utilisation of IMC may be viewed as one of the contributing factors to small retail business failure (Cohen, 2013). With this in mind the aim of the study was to investigate whether small retailers in the Mankweng township of Limpopo Province, South Africa make use of IMC to communicate with their customers. The objectives of the study were to a) Investigate whether small retailers in Mankweng Township utilise IMC as a marketing communication approach; b) To investigate whether small retailers in Mankweng make use of the elements of IMC to communicate with their target audience and; c) Establish whether IMC has a positive effect on the profitability of the small retailers in Mankweng. With these objectives in mind, the following hypotheses will be empirically tested:

H01: Small retailers in Mankweng utilise IMC as part of their marketing programme.

Ha1: Small retailers in Mankweng Township do not utilise IMC as part of their marketing programme. 
H02: There is a positive relationship between the utilisation of IMC and the profitability of small retailers in Mankweng Township.

Ha2: There is no positive relationship between the utilisation of IMC and the profitability of small retailers in Mankweng Township.

The significance of this study is that it investigates the utilisation of IMC at a micro-level that is at a small retailer/business level. This study is also significant in that it explores the adoption of IMC and its impact on the profitability of small retailers in a peri-urban area in the mostly rural Limpopo Province, South Africa.

\section{Review of Related Literature}

Integrated Marketing Communication (IMC) has gained prominence in the marketing field as a marketing communications approach (Eagle \& Kitchen, 2007). The integrated marketing communications mix is a comprehensive marketing communication plan that combines and evaluates a variety of strategic communication disciplines - general advertising, personal selling, sales promotion, direct marketing, public relations, sponsorships and others, to provide clarity, consistency and maximum communication impact (Du Plessis, Jooste \& Strydom, 2010). It follows then that IMC is perceived as an important concept for marketing retail businesses (Kokemuller, 2013), as one may argue that IMC has financial, competitive and effective benefits to be achieved through the synergy afforded by the process of integration (Yeshin, 2007; Dahlen, Lange \& Smith, 2010; Kehinde, 2011).

The generic IMC is made of six generic communication approaches. These are as illustrated in Figure 1, while literature on the individual elements is summarised in Table 1.

Figure 1: Elements of IMC

Source: Du Plessis et al (2010:5)

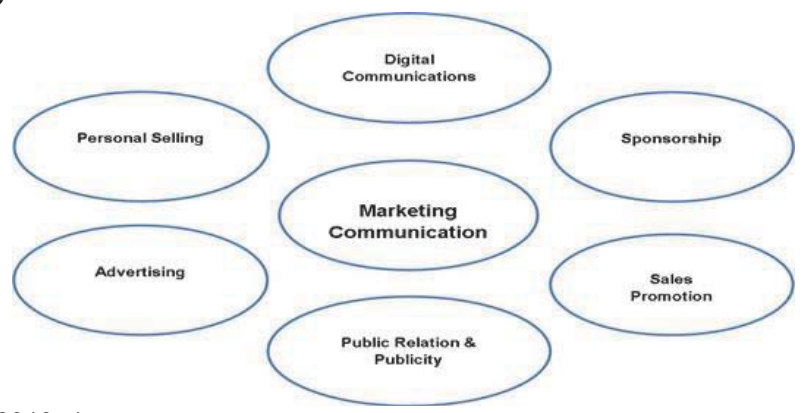

Table 1: Summary of literature on the elements of the IMC

\begin{tabular}{|l|l|}
\hline \multicolumn{1}{|c|}{ Element } & \multicolumn{1}{c|}{ Authors } \\
\hline Digital communications & $\begin{array}{l}\text { Abrahamsson \& Lundgren, 2004; Barker \& Angelopulo, 2006; Brown, 2011; Barak, 2012; } \\
\text { Sydney, 2012; Du Plessis et al., 2010 }\end{array}$ \\
\hline Personal selling & Beamish \& Ashford, 2006; Du Plessis et al., 2010; Riley, 2012 \\
\hline Advertising & Percy, 2008; Lake, 2013; Clough, 2013; Linwood 2013 \\
\hline Public relations & Tosun, 2004; Barker \& Angelopulo, 2006; Khodarahmi, 2009; Du Plessis et al., 2012 \\
\hline Publicity & Cox \& Brittain, 2000; Grace \& O'Cass, 2005; Du Plessis et al., 2010 \\
\hline Sales promotion & Barker \& Angelopulo, 2006; Riley, 2012; Weng \& De Run, 2013 \\
\hline Sponsorship & Cox \& Brittain, 2000; Smith \& Taylor, 2004; Sarah, Thomas, Pervan \& Nuttall , 2009 \\
\hline
\end{tabular}

The Integrated Marketing Communications (IMC) approach to marketing may be considered as the synthesis of the individual marketing promotion mix elements described in Table 1, in a bid to positively influence the outcome of consumer purchase decisions by offsetting the inherent disadvantages of one communication approach with the advantages of another (Polyorat, 2012; Stocia \& Cretoiu 2009; Nielsen, 2009). Among some of the factors that facilitate small business development, Tsikira, Muchenje and Katsidzira (2012) identify IMC as one such factor that ensures the expansion of a business by educating the market about the existence of the business, its products and its services. However, Eposito (2013) highlights that marketing communication by small businesses is subject to opposing internal and external forces, where dynamics external to the small business (e.g. competition) encourage or necessitate marketing 
communication, while internal factors (e.g. limited financial resources, lack of marketing skills) restrain investment in marketing communication.

According to Eposito (2013), there are limited empirical studies that focus specifically on IMC in the small business context. However, she cites studies by Low (2000), Kim and Fam (2001), Gabrielli and Baboni (2010) and Johnson (2000) which found IMC to be important to small business in Europe, as some studies that make reference to IMC and small business. In the African context however, Tsikirayi et al (2012) in the case of small businesses Zimbabwe found that the majority of small business owners and managers in Zimbabwe do not emphasize the importance of marketing communication, let alone IMC. This trend was also identified by Onah and Oguwo (1991) cited in Tsikirayi et al (2012), who in their study of Nigerian small businesses in relation to IMC practice found that small business owners in Nigeria paid little or no attention to IMC and that this orientation inhibited their growth and ability to compete with larger companies. This study seeks to determine if this trend is prevalent in small retailers in Mankweng, South Africa where small retailers are located in the same vicinity with large retailers.

\section{Methodology}

This study was conducted as a quantitative inquiry, aimed at generating numeric data that can be measured and analysed in order to test the hypothesis to be tested by the researcher. With the primary objective and nature of the study in mind, there is a compelling case for the empirical phase of intended study to be conducted as a quantitative inquiry (Neuman, 1997; Punch, 2003). The quantitative approach to research ideally seeks to test and/or verify theory rather than develop it. This focus on objective measurements and numerical analysis in testing and/or verifying hypotheses and theory respectively (Burns \& Grove, 2005; Gaiser\& Schreiner, 2009), made the quantitative paradigm suitable for the study.

\subsection{Population and Sample}

The study was conducted in the Mankweng area in Limpopo Province. The population comprised the small retailers that operate within the Mankweng area. This population was investigated to determine how effective their integrated marketing communication efforts were and also, to see how such efforts affect their profitability. The study identified a universal population of $N=37$ small retailers in the Mankweng area. Non-probability sampling was used to gather the data from the population. Purposive-convenience sampling was ideal for the study since all potential respondents were concentrated in the Mankweng commercial area. Purposive-convenience sampling assured the likelihood that all members of the universal population being selected for participation in the study had an opportunity to participate in the study (Salkind, 2012). Therefore, the total population of the study was all $N=37$ small retailers in the Mankweng area. However, according to RaoSoft (2013) online sample size calculator a random sample of $N=26$ respondents was sufficient for the generalising of the results of the study.

\subsection{Data Collection and Analysis}

The survey research method was employed to generate the quantitative data required for the study. A researcher administered questionnaire was utilised as the data collection instrument. A researcher-administered survey questionnaire is where respondents are asked a list of pre-formulated list of questions with a choice of pre-determined responses to choose from about their attitudes, activities, options, and believes towards specific research-related questions (Christensen, Johnson \& Turner, 2011). A questionnaire was formulated and directed to the small retailers within the Mankweng area with the aim to determine whether they employ IMC in their business and how IMC impacts on their profitability. The method that was used when conducting the survey was through personal interviews with face-toface interaction with respondents. The Statistical Package for Social Sciences (SPSS) version 21 was utilised to analyse the quantitative data collected by the researcher. Descriptive statistics and Correlation coefficient data analysis were employed to determine the relationship between variables that appear in the research hypothesis.

\section{Results}

Table 2 summarizes the response rate for the study. Thirty seven (37) small retailers were targeted, of which twenty six (26) were successfully completed. The remaining eleven (11) were not willing to participate. However, a response rate of $70.27 \%$ was maintained which was acceptable. 
Table 2: Response Rate

\begin{tabular}{|c|c|c|c|}
\hline Sample Size & Questionnaires Distributed & Questionnaires Completed & Response Rate \\
\hline 37 & 37 & 26 & $70.27 \%$ \\
\hline
\end{tabular}

\subsection{Demographics of Respondents}

Table 3 reflects the gender distribution of the respondents in the study. It is noted that 21 male participants (81\%) and 5 female participants $(19 \%)$ were surveyed. These results show that more males are operating small retail businesses in Mankweng than females.

Table 3: Respondents by Gender

\begin{tabular}{|c|c|c|c|c|}
\hline & Frequency & Percentage & Valid Percentage & Cumulative Percentage \\
\hline Male & 21 & 81 & 81 & 81 \\
\hline Female & 5 & 19 & 19 & 100.0 \\
\hline Total & 26 & 100.0 & 100.0 & \\
\hline
\end{tabular}

Table 4 summarizes the respondents operating small retail businesses in Mankweng by nationality. The majority of the small retailer businesses are operated by Indians. Eleven of the respondents were Indians (42.3\%), while 10 were Africans (38.5\%). 3 operators were white making up (11.5\%) of the respondents. Coloured operators and others, a Pakistani, accounted for $3.8 \%$ of the respondents, respectively. Table 4 also highlights that most small retail owners in Mankweng obtained high school education. This group was represented by 11 respondents $(42.3 \%)$. Degree holders made up 8 of the respondents $(30.8 \%)$, while 5 respondents (19.2\%) possessed a Diploma qualification. Only 2 respondents $(7.7 \%)$ had a primary education. Finally Table 4 categorises retailers by sector; stationary, grocery, clothing, furniture and general dealers. Out of twenty six respondents, three (3) respondents $(12 \%)$ were operating stationary related businesses, seven (7) respondents $(27 \%)$ were in the grocery business, three $(12 \%)$ were operating clothing stores, three $(12 \%)$ were furniture dealers and lastly, $10(38 \%)$ were general dealers.

Table 4: Retailer Nationality and Education Level

\begin{tabular}{|c|c|c|c|c|}
\hline & Frequency & Percentage & Valid Percentage & Cumulative Percentage \\
\hline \multicolumn{5}{|c|}{ Nationality of Respondents } \\
\hline African & 10 & 38.5 & 38.5 & 38.5 \\
\hline Indian & 11 & 42.3 & 42.3 & 80.8 \\
\hline Coloured & 1 & 3.8 & 3.8 & 84.6 \\
\hline White & 3 & 11.5 & 11.5 & 96.2 \\
\hline Other & 1 & 3.8 & 3.8 & 100.0 \\
\hline Total & 26 & 100.0 & 100.0 & \\
\hline \multicolumn{5}{|c|}{ Education Level of Respondents } \\
\hline Primary School & 2 & 7.7 & 7.7 & 7.7 \\
\hline Matric & 11 & 42.3 & 42.3 & 50.0 \\
\hline Diploma & 5 & 19.2 & 19.2 & 69.2 \\
\hline Degree & 8 & 30.8 & 30.8 & 100.0 \\
\hline Total & 26 & 100.0 & 100.0 & \\
\hline \multicolumn{5}{|c|}{ Profile of Respondents by Sector } \\
\hline Stationary & 3 & 12 & 11.5 & 11.5 \\
\hline Grocery & 7 & 27 & 26.9 & 38.5 \\
\hline Clothing & 3 & 12 & 11.5 & 50.0 \\
\hline Furniture & 3 & 12 & 11.5 & 61.5 \\
\hline General Dealers & 10 & 38 & 38.5 & 100.0 \\
\hline Total & 26 & 100.0 & 100.0 & \\
\hline
\end{tabular}




\subsection{The Marketing Communication Mix}

Respondents were asked if they employed any elements of the marketing mix in their business operations. Responses are summarised in Table 5 below;

Table 5: Utilisation of Marketing Communication Mix Elements

\begin{tabular}{|l|c|c|c|}
\hline & N & Mean & Std. Deviation \\
\hline Advertising & 26 & .615 & .4961 \\
Personal Selling & 26 & .692 & .4707 \\
Sales Promotion & 26 & .731 & .4523 \\
Digital Communication & 26 & .269 & .4523 \\
Publicity & 26 & .000 & .0000 \\
Sponsorship & 26 & .077 & .2717 \\
Direct Marketing & 26 & .077 & .2717 \\
Valid N & 26 & & \\
\hline
\end{tabular}

Table 5 shows the mean and standard deviation on the marketing communication mix that the respondents use in their businesses. The respondents were allowed to choose any number of the IMC elements. The descriptive statistics show that sales promotion, personal selling and advertising were the most used elements of IMC, with means of $0.731,0.692$ and 0.615 respectively. The use of elements such as digital communication, publicity, sponsorship and direct marketing were far less popular amongst the respondents.

\subsection{Customer Response to IMC}

Respondents were asked to rate the response they got from customers with regards to their IMC efforts. Table 6 summarises the responses;

Table 6: Response to IMC by customers

\begin{tabular}{|l|c|c|c|c|}
\hline & Frequency & Percentage & Valid Percentage & Cumulative Percentage \\
\hline Very bad & 1 & 4 & 4 & 3.8 \\
Bad & 3 & 12 & 12 & 15.4 \\
Moderate & 11 & 42 & 42 & 57.7 \\
Good & 10 & 38 & 38 & 96.2 \\
Very good & 1 & 4 & 4 & 100.0 \\
Total & 26 & 100.0 & 100.0 & \\
\hline
\end{tabular}

The results show that the majority of respondents indicated that they regard the response to IMC efforts as moderate $(42 \%)$. The second group indicated that the response to IMC by customer is good (38\%). However, $12 \%$ indicated that the response is bad, while one retail store $(4 \%)$ who participated indicated that the response to their IMC efforts was very good.

\subsection{Influence of IMC on consumer purchase decision-making}

Respondents were asked a closed question on whether they believed IMC influenced the decision of customers to make a purchase. The results summarised and analysed in Tables 7 and 8

Table 7: One Sample Statistics

\begin{tabular}{|c|c|c|c|c|}
\hline & $\mathbf{N}$ & Mean & Std. Deviation & Std. Error Mean \\
\hline MCS & 26 & 1.038 & .1961 & .0385 \\
\hline
\end{tabular}


Table 8: One sample T-test on the influence of IMC on consumer purchase decision

\begin{tabular}{|c|c|c|c|c|c|}
\hline \multicolumn{5}{|c|}{ Test Value $=.95$} \\
\cline { 5 - 6 } & $\mathrm{d}$ & Sig. (2-tailed) & Mean Difference & $95 \%$ Confidence Interval of the Difference \\
\cline { 5 - 6 } & & .030 & .0885 & Lower & Upper \\
\hline 2.300 & 25 & & .009 & .168 \\
\hline
\end{tabular}

Response to this question was either of Yes or No in which yes was coded as 1 and no coded as 2 . In Table 7, the mean $(\mu)$ of 1.038 indicates that most of the participants responded yes to this question. Table 8 shows the one simple test for the question on the effect of IMC on customers' purchasing decision making process. T-test is 2.3; degree of freedom (df) is $26-1=25$. The 2-tailed level of significance is 0.03 which is less than 0.05 ; mean difference is the mean from table 4.9 of $1.038-0.95=0.088$. The $95 \%$ confidence interval of the difference is 0.009 lower and 0.168 upper. The P-value is 0.03 which is less than 0.05 . This indicates that the respondents on the effect of IMC to the customer decision making is significantly different to $95 \%$. The test value is $95 \%$ which indicates the percentage of respondents who agree that the concept of IMC has an effect on customer purchasing decision making. It can be concluded that $95 \%$ of the respondents agreed to the question.

\subsection{Impact of IMC on Profitability}

Respondents were also asked how they perceived the impact of IMC on their profitability. Table 9 summarises their responses;

Table 9: Impact of IMC on Retailer Profitability

\begin{tabular}{|l|c|c|c|c|}
\hline & Frequency & Percentage & Valid Percentage & Cumulative Percentage \\
\hline Very Bad & 0.0 & 0.0 & 0.0 & .00 \\
Bad & 0.0 & 0.0 & 0.0 & 0.0 \\
Moderate & 2 & 7.7 & 12.5 & 12.5 \\
Good & 8 & 30.8 & 50.0 & 62.5 \\
Very Good & 2 & 7.7 & 12.5 & 75.0 \\
Don't Know & 4 & 15.4 & 25.0 & 100.0 \\
Total & 16 & 61.5 & 100.0 & \\
Missing System & 10 & 38.5 & & \\
Total & 26 & 100.0 & & \\
\hline
\end{tabular}

Table 9 indicates the respondents' opinion on how IMC contributes to the profitability of their businesses. Importantly, none of the respondents felt that IMC had a negative impact on their profitability. $7.7 \%$ of the respondents reported a moderate impact, with $30.8 \%$ and $7.7 \%$ perceiving a good and very good impact on profitability respectively. $4 \%$ did not know the impact that IMC had on their profitability. Interestingly $38.5 \%$ of the retailers did not respond to the question.

\section{Discussion and Conclusion}

The elements of marketing communications was not fully used in small businesses as the results show that some elements were used more than others, such as sales promotion personal selling and advertising. Respondents indicated that the response to their IMC efforts by their customers was moderate. Respondents also showed that the implementation of IMC strategies can positively influence the purchasing decision of customers. In this regard, they emphasised that as their customers have been influenced by their marketing communication efforts, it is evident that their sales and profits will also increase. Most of the retailers agree that elements of the IMC contributed a lot to increase the profitability of their businesses.

The effective use of IMC was evaluated in the Mankweng small retailers' domain. It was found that most of the respondents utilise some of the elements of IMC, while others, are rather less concerned about using any elements of IMC at all. Elements such as advertising, sales promotion and personal selling are being used by most of the respondents, while others like public relations, publicity, sponsorships and direct marketing were not fully integrated in 
their marketing activities. It remains important for small retailers to adopt the concept of IMC into their marketing programme, because it will help them to grow their businesses and to focus their communication efforts towards their target market allowing them to compete with larger retailers like Shoprite and Pick n' Pay which are also located in Mankweng. It was found that the elements of IMC play a vital role in the profitability of small retailers and that their customers tend to respond positively to the implementation of most of the elements of IMC. This means that if managers and owners of these stores can effectively implement the IMC elements, they can reap the benefits by generating more profits than before.

\subsection{Conclusion}

Based on the research findings, the study concludes;

a) The study finds that small retailers based in Mankweng Township utilise IMC as part of their marketing programme. Therefore we;

Accept - H01: Small retailers in Mankweng utilise IMC as part of their marketing programme.

Reject - Ha1: Small retailers in Mankweng Township do not utilise IMC as part of their marketing programme.

b) The study finds that there is a positive relationship between the utilisation of IMC and the profitability of small retailers in Mankweng. Therefore we;

Accept - H02: There is a positive relationship between the utilisation of IMC and the profitability of small retailers in Mankweng Township.

Reject - Ha2: There is no positive relationship between the utilisation of IMC and the profitability of small retailers in Mankweng Township.

\subsection{Recommendations}

The following recommendations are offered to improve the use of IMC in small retailers in order to increase their profits and growth.

i. $\quad$ There must be a marketing strategy that will direct the marketing communication of the business. This will entail the mission and objectives of marketing communication. It will help small retailers to analyse their target customers and focus their marketing message according to their requirements.

ii. Realistic and measurable objectives and goals must be set to direct their marketing communications. This will includes short and long term goals and objectives that retail store want to achieve.

iii. Accurate research must be done to determine which elements of IMC should be integrated in the marketing plan. The research could also provide small retailers with information about their customers to help them to create a database of current and potential customers. Business mentors may be appointed to assist them to structure their marketing strategies. Small businesses from this focused approach and will not waste resources on unwanted marketing instruments that may not benefit the business and also can help to focus the strategies for future implementation.

iv. Small retailers should develop marketing activities that evolve from their every-day operations and contact with their customers. Such a logical approach could develop long-term relationships with customers and create and sustain customer value and build a strong band and brand loyalty for the retailer and from customers respectively.

\section{References}

Abrahamsson, J.T \& Lundgren, H. (2004). The use of Web Sites in Integrated Marketing Communication 4 (74): 1-72. Lulea: University of Technology.

Barak, E. (2012). 3 Social Marketing Communication Methods: When \& How to Use Them. [Online] Available: http://searchenginewatch.com/article/2158216/3-Social-Marketing-Communication-Methods-When-How-to-Use-Them. (Accessed August 2, 2013).

Barker, R. \& Angelopulo, G. (2006). Integrated Marketing Communication; 1st Ed. Cape Town: Juta Academic.

Beamish, K. \& Ashford, R. (2006). Chartered Institute of Marketing: Course book - Marketing Planning; 1st Ed. USA: Butterworth Heinemann.

Brown, B. C. (2011). How to use the internet to Advertise, Promote, and Marketing Your Business or Website with Little or No Money; Revised, $2^{\text {nd }} E d$. USA: Atlantic Publishing Group Inc.

Burns, N \& Grove, S.K. (2005). The practice of nursing research: Conduct, critique and utilisation, 5th Ed. St Louis: Elsevier Sanders. 
Chen, H. J. (2009). Study of South African small retail businesses' utilisation of information resources, University of Johannesburg, 11 (3), pp 1-2.

Clough, M. (2013). Top 10 Advertising Tips For Small Business. [Online] Available: http://bestbizpractices.org/top-10-advertising-tips-forsmall-business/. (Accessed April 29, 2013).

Cohen, J. (2013). How to Start Your Own Retail Business from Preparation to Profitability. [Online] Available: http://business.solveyourproblem.com/retail business/small_retail_business_mistakes.shtml. (Accessed April 30, 2013).

Cox, R. \& Brittain, R. (2000). Framework Retail management, $4^{\text {th }}$ Ed. Financial Times: Prentice Hall.

Dahlen, M., Lange, F. \& Smith, T. (2010). Marketing communication. A Brand Narrative Approach. United Kingdom: John Wiley and Sons.

Du Plessis, F., Van Heerden, N. \& Cook, D. (2010). Integrated Marketing Communication, $3^{\text {rd }}$ Ed. South Africa: Van Schaik Publishers.

Eagle, L. \& Kitchen, J.P. (2007). Insights into Interpreting Integrated Marketing Communications: A two Nation Quantitative Comparison. European Journal of Marketing, 41(7/8), pp 956-970.

Esposito Annamaria. (2013). Insights about intergrated marketing communication in small-and-medium-sized Italian enterprises. Business Systems Review, 2(1), pp80-98.

Gaiser, T.J \& Schreiner, A.E (2009).A guide to conducting online research. London: Sage Publications Inc.

Grace, D. \& O'Cass, A. (2005). Examining the effects of service brand communications on brand evaluation. Journal of Product \& Brand Management, 14 (2), pp106-116.

Kehinde, OJ. (2011). Integrated Marketing Communication: A Catalyst for the Growth of E-Business Management. Academia.edu, 6 (2), pp64-73.

Khodarahmi, E. (2009).Strategic public relations, Disaster Prevention and Management. .Emerald Group Publishing Limited ,18 (5), pp 529-534.

Kokemuller, N. (2013). Retail Marketing \& Management for Beginners. [Online] Available: http://smallbusiness.chron.com/retailmarketing-management-beginners-42959.html. (Accessed on April 29, 2013).

Lake, L. 2013. Marketing vs. Advertising. [Online] Available: http://marketing.about.com/cs/advertising/a/marketvsad.htm._(Accessed on July 19, 2013).

Linwood, J. (2013). Types of Advertising Media. [Online] Available: http://www.knowthis.com/principles-of-marketing-tutorials/types-ofadvertising-media/. (Accessed April 30, 2013).

Marcomm, W.S. (2006). Performance consequences of brand equity management: Evidence from organisations in the value chain. Journal of Product and Brand Management, 12(4), pp220-236.

Neuman, W. L. (1997). Social Research Methods: Qualitative and Quantitative Approaches. Boston: Ally and Bacon.

Nielsen, L. (2009). Customer based brand equity: Evidence from the hotel industry. Journal of Managing Service Quality, 17(1), pp 92109.

Percy, L. (2008). Strategic Integrated Marketing Communication, $1^{\text {st }}$ Ed. Canada: Butterworth-Heinemann.

Polyorat, K. (2012).Integrated marketing communication for SME's organic fertilizer: The case study of men-gern. Department of Marketing/ECBER. Faculty of Management Science, Khonkaen University, Thailand.

Punch, K. (2003). Survey research: The basics. London: Sage publications Inc.

Riley, J. (2012). Promotional Mix-Personal Selling. [Online] Available: http://www.tutor2u.net/business/marketing/promotion_personalselling.asp. (Accessed July 14, 2013).

Rodringo, M.S. (2012). Implication of Integrated Marketing Communications. [Online] Available: http://writepass.co.uk/journal/2012/11/implication-of-integrated-marketing-communications/ (Accessed April 29, 2013).

Sarah, R., Thomas, S.J, Pervan P. \& Nuttall J.(2009). Marketing orientation and arts organisations: The case for business sponsorship. Marketing Intelligence \& Planning, 27 (6), pp 736-752.

Smith, P.R. \& Taylor, J. 2004. Marketing Communication. An Integrated Approach; $4^{\text {th }}$ Ed. United Kingdom

Stoica, Annamaria \& Cretoiu, R. (2009). Integrated communications- creating the right relations with the right customers. Annales Universitatis Apulenisis Seiues Oeconomica, 11(2), 1060-1065.

Sydney, A. (2012). Mobile communications the most important tool for marketers by 2015. [Online] Available: http://press.experian.com/Australia/Press-Release/mobile-communications-the-most-important-tool-for-marketers-by-2015.aspx. (Accessed July 18, 2013).

Tosun, N. (2004). Financial value and public relations Corporate Communications. An International Journal, 9(3), pp 202-208.

Tsikirayi, Catherine. M, Muchenje, B \& Katsidzira, Z. (Impact of intergrated communications mix (IMCM) in small to medium enterprises in Zimbabwe as a marketing tool. Research in Business \& Economic Journal, pp1-12.

Weng, J.K \& De Run, E.C. (2013). Consumers' personal values and sales promotion preferences effect on behavioural intention and purchase satisfaction for consumer product. Asia Pacific Journal of Marketing \& Logistics, 25(1), pp 70-101.

Yeshin, T. (2007). Advertising. Italy: Jennifer Pegg Publishing. 